\title{
An assessment of diatom assemblages in the Sea of Okhotsk as a proxy for sea-ice cover
}

\author{
Hiroki Nakamura ${ }^{1}$, Yusuke Okazaki ${ }^{1}$, Susumu Konno ${ }^{2}$, and Takeshi Nakatsuka ${ }^{3}$ \\ ${ }^{1}$ Department of Earth and Planetary Sciences, Graduate School of Science, \\ Kyushu University, 744 Motooka, Nishi-ku, Fukuoka 819-0395, Japan \\ ${ }^{2}$ Marine Works Japan Ltd, 2-15 Natsushima-cho, Yokosuka 237-0061, Japan \\ ${ }^{3}$ Graduate School of Environmental Studies, Nagoya University, \\ Furo-cho, Chikusa-ku, Nagoya 464-8601, Japan
}

Correspondence: Yusuke Okazaki (yokazaki@geo.kyushu-u.ac.jp)

Received: 4 September 2019 - Revised: 2 February 2020 - Accepted: 30 April 2020 - Published: 4 June 2020

\begin{abstract}
Knowledge of past variations in sea-ice extent is crucial for understanding the relationship between climate change and changes in sea ice. Diatom assemblages could be applied as a proxy for paleo-sea-ice extent; this requires accurate information on the modern species that are indicative of sea ice. Scanning electron microscope observations were performed on modern diatom assemblages in sea ice, sinking particles, and surface sediments in the Sea of Okhotsk. A sea-ice sample was collected in the southwestern Sea of Okhotsk near Hokkaido island in February 2013. Fragilariopsis cylindrus was the dominant diatom species in the sea-ice sample, accounting for $87 \%$ of the total diatom assemblage. Time-series sediment traps were deployed during 1998-2000 at two stations, M4 and M6, off Sakhalin island. Total diatom fluxes ranged from $10^{5}$ to $10^{8}$ valves $\mathrm{m}^{-2} \mathrm{~d}^{-1}$ with noticeable seasonality. During the sea-ice covering period, the total diatom flux decreased by 1 or 2 orders of magnitude. The highest diatom fluxes were observed in spring and summer. The diatom species composition in sinking particles also showed pronounced seasonal changes. During summer and fall, the Shionodiscus trifultus group and Neodenticula seminae were the major diatom taxa. During the sea-ice covering period, Fragilariopsis cylindrus and Bacterosira bathyomphala resting spores were abundant. Both the sea-ice-related species showed similar flux patterns except for the spring bloom after sea-ice retreat: F. cylindrus fluxes exhibited pronounced spring bloom peaks of $10^{8}$ valves $\mathrm{m}^{-2} \mathrm{~d}^{-1}$; in contrast, the fluxes of Bacterosira bathyomphala resting spores during the spring bloom were 1 order of magnitude lower than those of $F$. cylindrus. Surface-sediment core XP98-MC4 was obtained near station M6 sediment-trap site off Sakhalin island. The relative abundance of Fragilariopsis cylindrus in the surface-sediment diatom assemblage was only $6.4 \%$, markedly lower than that in the sediment-trap samples $(43.4 \%)$. In the surface sediment, the relative abundances of diatom taxa with heavily silicified valves such as B. bathyomphala resting spores, Shionodiscus variantius, and Thalassionema nitzschioides were greater than their relative abundances in sinking particles.
\end{abstract}

\section{Introductions}

Ice plays an important role in the Earth's climate system owing to its albedo effect and its insulation effect on heat exchange between the atmosphere and the ocean. Furthermore, as a result of brine rejection during sea-ice formation, briny water sinks to the ocean interior, influencing thermohaline circulation. The Sea of Okhotsk is a marginal sea in the western North Pacific (Fig. 1). One of the most notable features of the Sea of Okhotsk is the seasonal sea-ice cover from winter to early spring, constituting the southernmost sea-ice area in the Northern Hemisphere. The area of sea-ice cover in the Sea of Okhotsk exhibits large variations both seasonally and annually; there is no sea ice from June to November, and up to $\sim 75 \%$ of the area is covered with sea ice in February to March (e.g., Ohshima et al., 2006). The long-term trend in the maximum sea-ice extent in the Sea of Okhotsk is of a 
gradual decrease of $4.4 \%$ per decade since 1970 with large interannual variations (Nakanowatari et al., 2007; Japan Meteorological Agency, 2017). Sea-ice production also shows a significant decreasing trend mainly due to the warming of fall air temperatures (Kashiwase et al., 2014). This declining trend is widely observed in Northern Hemisphere sea ice, particularly in the Arctic Ocean (Vinnikov et al., 1999; Serreze et al., 2000; Stroeve et al., 2007, 2012). Observational data on sea-ice extent in the Sea of Okhotsk are available for $\sim 50$ years. Long-term sea-ice extent data are essential to evaluate the relationship between global warming and the decline of sea-ice extent. Paleo-proxy data can contribute to understanding the long-term sea-ice variations at centennial, millennial, and orbital timescales beyond the range of observational data.

Ice algae live in and under the sea ice and play a principal role in primary production in sea-ice areas (e.g., Syvertsen, 1991). In the Sea of Okhotsk, ice-algal diatoms are the majority of ice algae. Diatom frustules are composed of biogenic opal and can be preserved in sediments. Therefore, microfossils of ice-algal diatoms in sediments provide evidence of the presence of sea ice in the past. Indeed, the sea-ice history in the Sea of Okhotsk has been reconstructed mainly on the basis of two paleo-proxies preserved in sediments: (1) icerafted debris (Nürnberg and Tiedemann, 2004; Sakamoto et al., 2005, 2006; Nürnberg et al., 2011; Yamazaki et al., 2013; Vasilenko et al., 2017; Wang et al., 2017) and (2) seaice-related diatom species (Sancetta, 1981, 1982; Shiga and Koizumi, 2000; Koizumi et al., 2003; Shimada et al., 2004; Okazaki et al., 2005; Gorbarenko et al., 2007, 2010, 2014; Wang and Wang, 2008; Katsuki et al., 2010; Harada et al., 2014; Matul, 2017; Artemova et al., 2017). However, in the Sea of Okhotsk, direct observations of diatoms in and under sea ice are very limited. Asami and Imada (2001) and McMinn et al. (2008) reported diatom assemblages in sea ice from the Notoro-ko Lagoon, the Saroma-ko Lagoon, and the Shiretoko coast, all of which are coastal sites in Hokkaido, Japan. Consequently, our knowledge of ice algae in the Sea of Okhotsk remains at a preliminary stage. This lack of information hampers attempts to reconstruct past sea-ice cover based on the sedimentary records of diatom assemblages. Recently, a biomarker named IP25 (ice proxy with 25 carbon atoms), which is produced by ice-algal diatoms, has been proposed as a sea-ice paleo-proxy for the Arctic Ocean (Belt et al., 2007; Belt and Muller, 2013). Lo et al. (2018) applied IP25 to reconstruct the sea-ice history of the past $130 \mathrm{kyr}$ in the central Sea of Okhotsk. Although IP25 is a promising paleo-proxy for sea-ice cover, it is also essential to identify the diatom species living in and under the sea ice in the Sea of Okhotsk, because not all ice-algal diatoms produce IP25.

Here we present seasonal diatom fluxes based on scanning electron microscope (SEM) observations of diatoms from samples obtained between August 1998 and June 2000 at two sediment-trap stations deployed off Sakhalin in the western Sea of Okhotsk, where seasonal sea-ice cover is present during winter and spring. This is the first attempt to clarify the diatom assemblages in sinking-particle samples collected under sea-ice cover in the Sea of Okhotsk. We also investigated the diatom assemblages in a sea-ice sample obtained near the coast of Hokkaido, southern Sea of Okhotsk, in February 2013. Although the diatom assemblage in this sea-ice sample is a snapshot datum and the sampling location and sampling period are different from those of the sediment-trap samples, these data provide supporting evidence to identify ice-algal diatom taxa living in sea ice in the Sea of Okhotsk. Finally, we studied the diatom assemblage in surface sediment obtained near the sediment-trap site off Sakhalin. By comparing the diatom assemblages in sinking particles and sediments, we evaluated the alteration of diatom species composition during sinking and sedimentation. The purpose of this study was to clarify what kinds of diatom species are living in and under the sea ice of the Sea of Okhotsk and how they are preserved in sediment. The results of the study provide fundamental information for the reconstruction of past sea-ice cover based on ice-algal diatoms in sediments of the Sea of Okhotsk and the subarctic Pacific.

\section{Oceanographic setting}

Sea ice in the Sea of Okhotsk is mainly formed in polynyas located in the northern and Sakhalin coastal areas (Martin et al., 1998; Kimura and Wakatsuchi, 2004). Sea ice formed in coastal polynyas is advected by wind and ocean currents. In the Sea of Okhotsk, sea-ice advance is mainly driven by prevailing northerly and northwesterly winds in winter, governed by an interaction between the Siberian High and the Aleutian Low (Martin et al., 1998; Ohshima et al., 2006). The Sea of Okhotsk has a counterclockwise surface water circulation (the Okhotsk Gyre) as a part of the subarctic circulation system in the North Pacific (Dodimead et al., 1963; Favorite et al., 1976). Along the Sakhalin coast, the East Sakhalin Current flows southward (Ohshima et al., 2002), which advects sea ice to the southern Sea of Okhotsk. As a result, sea ice in the Sea of Okhotsk starts to cover the northwestern continental shelves near the Amur River mouth in November and expands southeastwardly (Ohshima et al., 2006). Maximum sea-ice extents have been recorded from February to March, covering $50 \%$ to $90 \%$ (average $\sim 75 \%$ ) of the sea.

Dense shelf water is formed in association with brine rejection in the coastal polynya on the northwestern shelf of the Sea of Okhotsk (Martin et al., 1998; Shcherbina et al., 2003). Dense shelf water is transported to the south by the East Sakhalin Current and forms the Sea of Okhotsk Intermediate Water (SOIW) as a result of mixing with waters originating from the Sea of Japan and the subarctic Pacific (Itoh et al., 2003). Because the SOIW is a source of North Pacific Intermediate Water, sea-ice formation in the Sea of Okhotsk plays a key role in ocean ventilation in the North Pacific (Talley, 1991; Yasuda, 1997; Shcherbina et al., 2003). 


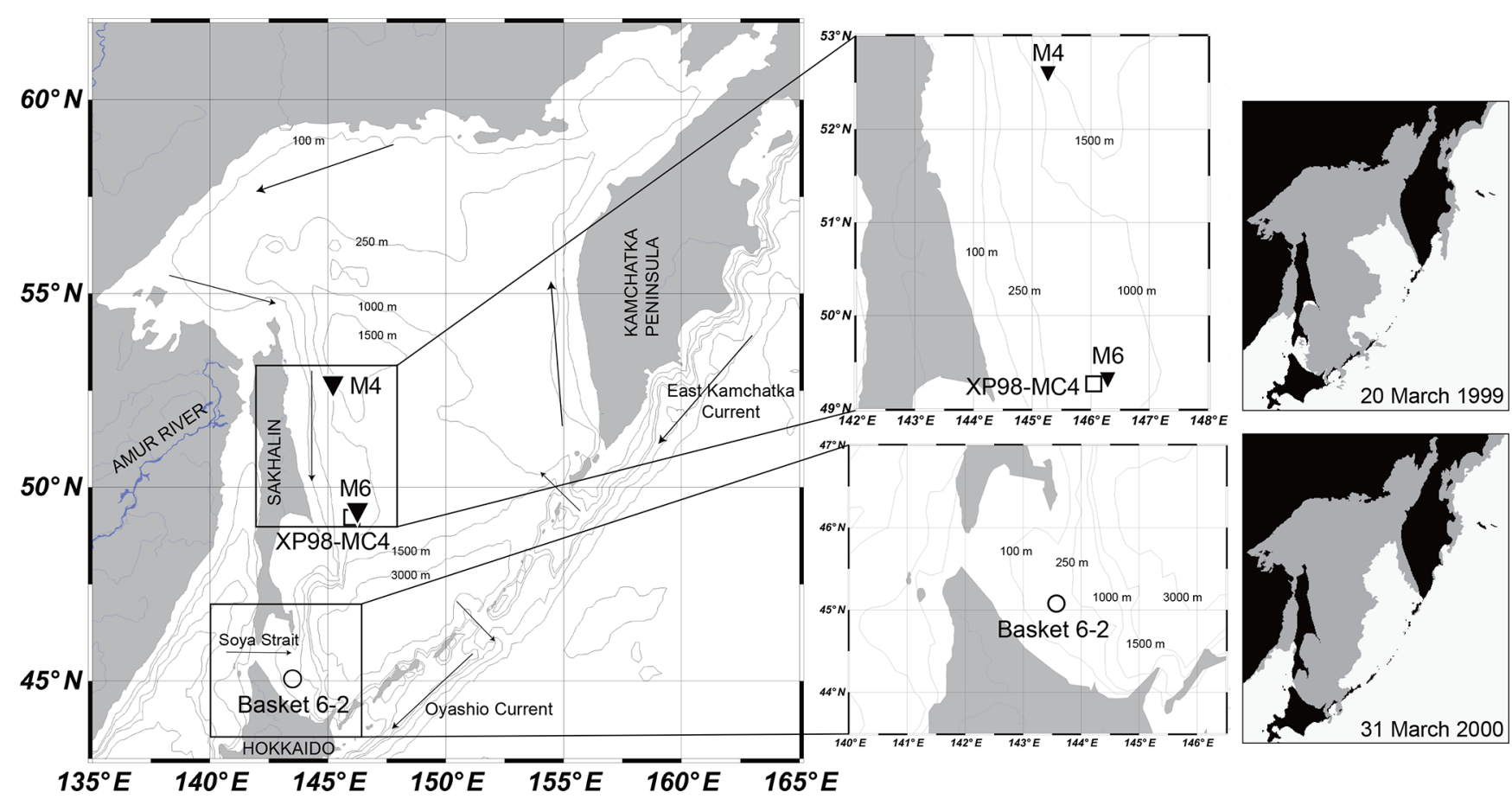

Figure 1. Locations of sediment-trap stations M4 and M6 (solid triangles), sea-ice sample Basket 6-2 (open circle), and surface-sediment core XP98-MC4 (open square) in the Sea of Okhotsk. Gray areas in the panels on the right denote maximum sea-ice coverage in 1999 and 2000 during sediment-trap deployment at stations M4 and M6.

High primary production is another feature of the Sea of Okhotsk, particularly off Sakhalin (Saitoh et al., 1996; Behrenfeld and Falkowski, 1997; Sorokin and Sorokin, 1999, 2002; Matsumoto et al., 2004). Matsumoto et al. (2004) reported the occurrence of ice-edge blooms in the northwestern continental shelves of the Sea of Okhotsk in late spring subsequent to sea-ice retreat. In contrast, during the sea-ice cover period in winter, primary production in the Sea of Okhotsk is low (Matsumoto et al., 2004). Asami and Imada (2001) reported blooms of specific diatom taxa such as Fragilaria spp. and Navicula spp. in sea ice of the Notoro-ko Lagoon, north coast of Hokkaido island, Japan. Such diatom blooms are likely to be recorded as high opal fluxes in sediment-trap samples collected from off Sakhalin (Nakatsuka et al., 2004). However, diatom assemblage data for sinking particles have not previously been available (Nakatsuka et al., 2004).

\section{Materials and methods}

Sea-ice, sinking-particle, and surface-sediment samples were used for SEM observations of diatom assemblages (Table 1; Fig. 1).

\subsection{Sea-ice samples}

A sea-ice sample was obtained during the SOYA2013 cruise of Soya, an icebreaker patrol ship of the Japan Coast Guard. Jun Nishioka of Hokkaido University collected a sea-ice sample (brown ice) at station Basket 6-2 near the Hokkaido coast $\left(45^{\circ} 09.88^{\prime} \mathrm{N}, 143^{\circ} 58.33^{\prime} \mathrm{E}\right)$ on 28 February 2013 (Table 1). The sea-ice sample was stored in a freezer at Hokkaido University, and a partial sample weighing approximately $1 \mathrm{~kg}$ was transported to Kyushu University in February 2016. The sea-ice sample was melted at room temperature in a glass beaker and filtered through an Advantec membrane filter $(0.45 \mu \mathrm{m}$ pore size, $47 \mathrm{~mm}$ diameter $)$. The filtered sample was desalted with Millipore Elix ${ }^{\circledR}$ water and dried in an oven at $40^{\circ} \mathrm{C}$ overnight.

\subsection{Sediment-trap samples}

Time-series sediment traps (McLane PARFLUX Mark 78G21; McLane Research Laboratories Inc., East Falmouth, MA, USA) were moored at two stations, M4 and M6, off Sakhalin from July 1998 to June 2000 (Table 1; Nakatsuka et al., 2004). Deployments and recoveries of the sediment traps were performed onboard R/V Professor Khromov (Far Eastern Regional Hydrometeorological Research Institute, Russia) during three cruises in July 1998, September 1999, and June 2000. At both stations, two sediment traps were moored at different water depths (Table 1; Nakatsuka et al., 2004). Each sediment trap was equipped with 21 sampling cups, and time-series sinking-particle samples were collected over the course of a year. Sampling intervals were equally divided for each of the 21 sampling cups in each deployment year (17.4 d in 1998-1999 at both M4 and M6; $13.0 \mathrm{~d}$ in 1999- 
Table 1. Summary information for samples used in this study: sediment traps, sea ice, and surface sediment from the Sea of Okhotsk.

\begin{tabular}{|c|c|c|c|c|c|}
\hline Sediment trap ID & Latitude & Longitude & $\begin{array}{r}\text { Water depth } \\
(\mathrm{m})\end{array}$ & $\begin{array}{l}\text { Sampling period } \\
\text { (mooring period) }\end{array}$ & $\begin{array}{r}\text { Mooring depth } \\
(\mathrm{m})\end{array}$ \\
\hline M4 (1998-1999) & $52^{\circ} 58.99^{\prime} \mathrm{N}$ & $145^{\circ} 28.57^{\prime} \mathrm{E}$ & 1729 & $\begin{array}{l}7 \text { Aug } 1998 \text { to } 7 \text { Aug } 1999 \\
\text { (29 Jul } 1998 \text { to } 6 \text { Sep } 1999 \text { ) }\end{array}$ & 280,1547 \\
\hline M4 (1999-2000) & $53^{\circ} 01.25^{\prime} \mathrm{N}$ & $145^{\circ} 30.25^{\prime} \mathrm{E}$ & 1722 & $\begin{array}{l}8 \text { Sep } 1999 \text { to } 7 \text { Jun } 2000 \\
\text { (6 Sep } 1999 \text { to } 17 \text { Jun } 2000\end{array}$ & 259,1530 \\
\hline M6 (1998-1999) & $49^{\circ} 30.63^{\prime} \mathrm{N}$ & $146^{\circ} 30.33^{\prime} \mathrm{E}$ & 794 & $\begin{array}{l}7 \text { Aug } 1998 \text { to } 7 \text { Aug } 1999 \\
\text { (2 Aug } 1998 \text { to } 4 \text { Sep } 1999 \text { ) }\end{array}$ & 278,693 \\
\hline M6 (1999-2000) & $49^{\circ} 30.53^{\prime} \mathrm{N}$ & $146^{\circ} 28.74^{\prime} \mathrm{E}$ & 783 & $\begin{array}{l}27 \text { Sep } 1999 \text { to } 6 \text { Jun } 2000 \\
\text { (24 Sep } 1999 \text { to } 15 \text { Jun } 2000 \text { ) }\end{array}$ & 268,682 \\
\hline Sea-ice ID & Latitude & Longitude & $\begin{array}{r}\text { Water depth } \\
(\mathrm{m})\end{array}$ & Sampling period & \\
\hline Basket 6-2 & $45^{\circ} 09.88^{\prime} \mathrm{N}$ & $143^{\circ} 58.33^{\prime} \mathrm{E}$ & $\mathrm{n} / \mathrm{a}$ & 28 Feb 2013 & \\
\hline Sediment core ID & Latitude & Longitude & $\begin{array}{r}\text { Water depth } \\
(\mathrm{m})\end{array}$ & $\begin{array}{l}\text { Core length } \\
(\mathrm{cm})\end{array}$ & \\
\hline XР98-MC4 & $49^{\circ} 29.8^{\prime} \mathrm{N}$ & $146^{\circ} 07.2^{\prime} \mathrm{E}$ & 661 & 22 & \\
\hline
\end{tabular}

n/a - not applicable.

2000 at M4; and $12.1 \mathrm{~d}$ in 1999-2000 at M6). There were periods of sample hiatuses without trap deployments because of the cruise schedule: 8 August to 7 September 1999 at M4 and 8 August to 26 September 1999 at M6. To avoid in situ microbial decomposition of sinking particles, all cups were filled with Okhotsk deep water containing $5 \%$ formaldehyde solution neutralized by sodium tetraborate before the deployment of the sediment traps. After recovery of the sediment traps, sample cups were immediately removed from the trap and stored in a refrigerator at a shore-based laboratory.

For diatom assemblage analyses, we used a total of 84 samples from the M4 and M6 upper traps moored between 250 and $300 \mathrm{~m}$ water depth (Table 1). The sediment-trap samples used in this study were stored in a refrigerator at Kyushu University at $\sim 5^{\circ} \mathrm{C}$ (Okazaki et al., 2003). These samples were sieved through a stainless steel testing sieve with $1 \mathrm{~mm}$ mesh to remove swimmers, then split to an aliquot size of $1 / 132$ to $1 / 8448$ using a wet sample divider (McLane Research Laboratories Inc., East Falmouth, MA, USA). These samples were filtered through an Advantec membrane filter ( $0.45 \mu \mathrm{m}$ pore size, $47 \mathrm{~mm}$ diameter), desalted with Millipore Elix ${ }^{\circledR}$ water, and then dried in an oven at $40^{\circ} \mathrm{C}$ overnight.

\subsection{Surface-sediment samples}

A surface-sediment sample was obtained during the R/V Professor Khromov cruise in July 1998. A multiple core (XP98MC4) was obtained from off Sakhalin near sediment-trap station M6 (Table 1). XP98-MC4 core samples were sliced at $1 \mathrm{~cm}$ intervals and stored in a refrigerator at Kyushu University. The core-top sample of XP98-MC4 was freeze-dried with an EYELA FDU-1200 freeze dryer. Approximately $1 \mathrm{mg}$ of the freeze-dried sample was treated with $25 \mathrm{~mL}$ of $10 \%$ hydrogen peroxide at $\sim 70^{\circ} \mathrm{C}$ for about $1 \mathrm{~h}$ to digest organic matter. After the reaction was complete, Millipore Elix ${ }^{\circledR}$ water was added to a total volume of $200 \mathrm{~mL}$ and allowed to stand for $8 \mathrm{~h}$. The supernatant was removed, and Millipore Elix ${ }^{\circledR}$ water was added again. Then, these samples were filtered through an Advantec membrane filter $(0.45 \mu \mathrm{m}$ pore size, $47 \mathrm{~mm}$ diameter), rinsed with Millipore Elix ${ }^{\circledR}$ water, and dried in an oven at $40^{\circ} \mathrm{C}$ overnight. The sedimentation rate of XP98-MC4 was estimated to be $28.3 \mathrm{~cm} \mathrm{kyr}^{-1}$ (Seki et al., 2004); therefore, the $1 \mathrm{~cm}$ thick core-top sample of XP98-MC4 records $\sim 35$ years.

\subsection{Scanning electron microscope observations}

Pretreated filter samples of sea-ice, sediment-trap, and surface-sediment samples were cut into $6 \mathrm{~mm} \times 6 \mathrm{~mm}$ squares, mounted onto brass stubs with carbon tape, and coated with $\mathrm{OsO}_{4}$ using an osmium coater (Neoc-STB; Meiwafosis Co. Ltd., Tokyo, Japan). A field emission scanning electron microscope (FE-SEM; JMS-7001F; JEOL Ltd., Akishima, Japan) was used for the identification and counting of the diatoms. SEM observations were made at magnifications of $1000 \times$ to $2000 \times$. The acceleration voltage was set at $5 \mathrm{kV}$ and the working distance at $8.9 \mathrm{~mm}$.

Counting of diatom valves was performed as follows: (1) for centric diatoms, a valve with a central part was counted as one valve; (2) for pennate diatoms, a valve with an apical part was counted as 0.5 valve; and (3) Chaetoceros resting spores were counted separately. More than 300 di- 
atom valves were counted for diatom assemblage analyses of sea-ice and surface-sediment samples. For sediment-trap samples, we counted diatom valves along a line of the field of view to calculate their flux (no. valves $\mathrm{m}^{-2} \mathrm{~d}^{-1}$ ). For example, when counting at a magnification of $1000 \times$, the width of the field of view is $200 \mu \mathrm{m}$. As the length of one side of a filter sample mounted on a stub is $6 \mathrm{~mm}$, the area of one line of the field of view is $0.2 \times 6=1.2 \mathrm{~mm}^{2}$. We counted diatom valves along a line of the field of view until the total number of diatom valves exceeded 100 or the total area of the filter $(6 \mathrm{~mm} \times 6 \mathrm{~mm})$ had been covered. Diatom fluxes were calculated by the following equation:

diatom flux (valves $\mathrm{m}^{-2} \mathrm{~d}^{-1}$ ) $=$

$$
(N / S / D) \times\left(S_{1} / S_{2}\right) \times V,
$$

where $N$ is the number of diatom valves counted, $S$ is the aperture area of the sediment trap $\left(0.5 \mathrm{~m}^{2}\right), D$ is the sampling interval (Table 1), $S_{1}$ is the area of the filter sample $\left(\mathrm{mm}^{2}\right)$, $S_{2}$ is the counted area $\left(\mathrm{mm}^{2}\right)$, and $V$ is the aliquot size.

Identification and counting were conducted at species level as much as possible. Images of observed diatom taxa are shown in Plates S1-S3 in the Supplement. Chaetoceros resting spores (Plate S3; Figs. 2-4) were excluded from the diatom assemblage analysis, as in previous studies (e.g., Shiga and Koizumi, 2000; Onodera et al., 2005). The relative abundances of diatom taxa in this study were calculated except for Chaetoceros resting spores; however, we included Bacterosira bathyomphala resting spores (synonym: B. fragilis) (Plate S1; Figs. 1-2) in the diatom assemblage, following the method used in previous studies (Shiga and Koizumi, 2000; Shimada et al., 2004; Okazaki et al., 2005; Gorbarenko et al., 2007; Katsuki et al., 2010). Thus, it is easy to compare our diatom assemblage data with those of previous studies.

\subsection{Stages of sea-ice coverage}

Nakatsuka et al. (2004) provided time-series sea-ice concentration changes for stations M4 and M6 during 1998-2000. In this study, we divided the sea-ice conditions into four stages (Fig. 2): (1) the sea-ice-free stage, with a sea-ice concentration of zero from the end of the sea-ice coverage in spring till the first sea-ice coverage in winter; (2) the early sea-ice cover stage, from the first sea-ice coverage till the final seaice concentration minimum in January or February; (3) the maximum sea-ice cover stage, with the maximum sea-ice concentration (late winter to early spring); and (4) the late sea-ice cover stage, with a low sea-ice concentration in late spring after the sea-ice maximum.

\section{Results}

\subsection{Diatom assemblage in sea ice}

Nine diatom taxa were found in sea-ice sample station Basket 6-2 (Table 2). Fragilariopsis cylindrus accounted for
$87 \%$ of the total diatom assemblage. The relative abundance of each of the other eight taxa was less than $5 \%$.

\subsection{Diatom fluxes and assemblages in sinking particles}

The temporal fluxes of total diatoms at stations M4 and M6 during 1998-2000 are shown in Fig. 2. Total diatom fluxes (excluding Chaetoceros resting spores) ranged from $10^{4}$ to $10^{8}$ valves $\mathrm{m}^{-2} \mathrm{~d}^{-1}$ and relatively low fluxes were observed when sea-ice cover was present. In general, the fluxes during sea-ice coverage were 1 to 2 orders of magnitude lower than those during open water. The highest flux peaks were observed during the late sea-ice cover stage and the subsequent sea-ice-free stage in spring to early summer. Similar patterns were observed for the fluxes of Chaetoceros resting spores at stations M4 and M6 during 1998-2000 (Fig. 2). The exception was in June-July 1999, when no Chaetoceros resting spores were found.

Fifty-six diatom taxa were observed in sinking-particle samples at stations M4 and M6 (Table 2; Plates S1-S3). The taxonomic compositions showed pronounced seasonal changes (Fig. 3). During the sea-ice-free stage, the major diatom taxa were Neodenticula seminae and the Shionodiscus trifultus group. In 1999, Proboscia eumorpha/subarctica exhibited relatively high abundances. During the early sea-ice cover stage, Bacterosira bathyomphala (as resting spores) was the representative species. Fragilariopsis cylindrus, $N$. seminae, and Thalassionema nitzschioides made considerable contributions to the diatom assemblages. During the maximum sea-ice cover stage, F. cylindrus and B. bathyomphala resting spores were the major diatom taxa; in particular, very high percentages of $F$. cylindrus $(>60 \%)$ were observed during spring 2000 at both station M4 and station M6. Markedly high fluxes and relative abundances of $F$. cylindrus were observed during the late sea-ice cover stage and the subsequent sea-ice-free stage. Most of the diatom taxa also showed high fluxes during late spring to early summer, but only $F$. cylindrus made up enormously high percentages of the assemblages. Temporal flux changes in Fragilariopsis oceanica/pseudonana/reginae-jahniae were similar to those of $F$. cylindrus. Throughout the observations, the relative abundances of Thalassiosira antarctica/bulbosa/hyalina/nordenskioeldii were lower than $10 \%$.

\subsection{Diatom fluxes and assemblages in surface sediment}

Twenty-eight diatom taxa were found in surface-sediment sample XP98-MC4 (Table 2; Plates S1-S3). Major diatom taxa (relative abundance $>5 \%$ ) were $B$. bathyomphala resting spores, F. cylindrus, F. oceanica/pseudonana/reginaejahniae, $N$. seminae, the $S$. trifultus group, $S$. variantius, $T$. nitzschioides, Thalassiosira hyalina, and Thalassiosira nordenskioeldii. 
Table 2. Relative abundances of diatom taxa in sediment-trap, sea-ice, and surface-sediment samples. Note that the relative abundances of diatom taxa were calculated excluding Chaetoceros resting spores.

\begin{tabular}{|c|c|c|c|c|c|c|}
\hline \multirow[t]{2}{*}{ Diatom taxa } & \multicolumn{2}{|c|}{ M4 } & \multicolumn{2}{|c|}{ M6 } & \multirow[t]{2}{*}{ Sea ice } & \multirow[t]{2}{*}{ Sediment } \\
\hline & 1998-1999 & 1999-2000 & 1998-1999 & 1999-2000 & & \\
\hline Actinocyclus curvatulus Janisch & 1.6 & 0.8 & 1.9 & 0.1 & - & 1.5 \\
\hline Actinocyclus ochotensis Jousé & 0.0 & 0.4 & - & 0.0 & - & - \\
\hline Actinocyclus spp. & 0.3 & 0.3 & 1.7 & 0.1 & - & 4.1 \\
\hline Amphola sp. & - & 0.0 & 0.0 & 0.0 & - & - \\
\hline Asteromphalus hyalinus Karsten & 0.1 & 0.2 & 0.0 & 0.0 & - & 0.3 \\
\hline Aulacoseira sp. & - & 0.2 & 0.0 & 0.0 & - & - \\
\hline Bacterosira bathyomphala (Gran) Syvertsen and Hasle & 0.1 & 0.3 & 0.4 & 0.6 & - & 0.6 \\
\hline Bacterosira bathyomphala (Gran) Syvertsen and Hasle resting spores & 0.8 & 5.7 & 0.7 & 4.7 & - & 10.8 \\
\hline Biddulphia spp. & - & 1.5 & - & 0.6 & - & - \\
\hline Chaetoceros atlanticus Cleve & 2.4 & 1.1 & 2.1 & 0.0 & - & - \\
\hline Chaetoceros spp. & 1.7 & - & 4.0 & - & 4.7 & - \\
\hline Corethron sp. & 0.0 & 0.1 & - & - & - & - \\
\hline Coscinodiscus spp. & 0.0 & - & 0.0 & - & - & 0.6 \\
\hline Cyclotella spp. & 0.3 & 0.4 & 0.0 & 0.1 & - & - \\
\hline Delphineis minutissima (Hustedt) Simonsen & 0.0 & 0.4 & 0.0 & 0.1 & - & 0.1 \\
\hline Detonula confervacea (Cleve) Gran & 0.1 & 0.6 & 1.0 & 0.6 & - & 2.0 \\
\hline Ditylum spp. & 0.0 & - & 0.0 & - & - & - \\
\hline Fragilariopsis curta (Van Heurck) Hustedt & 0.0 & 0.4 & - & 0.1 & - & - \\
\hline Fragilariopsis cylindrus (Grunow) Krieger & 52.1 & 31.3 & 43.9 & 55.1 & 86.5 & 6.4 \\
\hline $\begin{array}{l}\text { Fragilariopsis oceanica (Cleve) Hasle, pseudonana (Hasle) Hasle, } \\
\text { and reginae-jahniae Witkowski, Lange-Bertalot and Metzeltin }\end{array}$ & 6.9 & 7.7 & 4.2 & 4.5 & - & 6.4 \\
\hline Fragilariopsis spp. & 0.0 & - & - & - & - & 0.1 \\
\hline Minidiscus variabilis Kaczmarska & 0.0 & 1.4 & - & 0.0 & 0.3 & - \\
\hline Navicula kariana var. detersa Grunow & 0.0 & 3.9 & 0.8 & 3.9 & 0.9 & - \\
\hline Navicula spp. & 0.0 & 2.1 & 0.0 & 0.0 & - & 0.3 \\
\hline Neodenticula seminae (Siomonsen and Kanaya) Akiba and Yanagisawa & 10.2 & 12.2 & 8.2 & 13.2 & - & 9.1 \\
\hline Nitzschia spp. & 0.1 & - & 0.0 & 0.0 & - & - \\
\hline Odontella sp. & - & - & 0.0 & - & - & - \\
\hline Paralia marina (Smith) Heiberg & 0.1 & 0.3 & 0.0 & 0.1 & - & 2.3 \\
\hline Paralia sulcata (Ehrenberg) Cleve & 0.0 & - & - & - & - & - \\
\hline Pleurosigma sp. & 0.1 & 0.6 & 0.0 & 0.1 & - & - \\
\hline Porosira glacialis (Grunow) Jørgensen & 0.0 & 0.1 & 0.3 & 0.1 & 0.9 & - \\
\hline Proboscia eumorpha Takahashi, Jordan and Priddle & 1.2 & 5.1 & 6.1 & 0.3 & - & - \\
\hline Proboscia subarctica Takahashi, Jordan and Priddle & 0.2 & 3.3 & 1.4 & 0.9 & - & - \\
\hline Proboscia spp. & 0.0 & 0.3 & - & - & - & - \\
\hline Psammothidium spp. & - & 0.9 & - & - & - & - \\
\hline Rhizosolenia spp. & 0.0 & 0.2 & 0.2 & - & - & 0.3 \\
\hline Shionodiscus oestrupii (Ostenfeld) Alverson, Kang and Theriot & 0.0 & - & - & - & - & - \\
\hline Shionodiscus trifultus (Fryxell) Alverson, Kang and Theriot group & 7.6 & 5.0 & 10.5 & 2.3 & 0.6 & 12.0 \\
\hline Shionodiscus variantius (Shiono) Alverson, Kang and Theriot & 5.3 & 4.6 & 2.8 & 3.8 & - & 8.2 \\
\hline Shionodiscus sp. & 0.0 & - & 0.3 & 0.0 & - & - \\
\hline Skeletonema costatum (Greville) Cleve & - & 0.3 & - & 0.2 & - & 0.3 \\
\hline Staurosira sp. & - & 0.1 & - & - & - & - \\
\hline Thalassionema nitzschioides (Grunow) Mereschkowsky & 0.6 & 1.7 & 0.7 & 1.4 & - & 11.6 \\
\hline Thalassiosira antarctica Comber & 6.6 & 0.1 & 0.1 & 3.8 & - & 0.3 \\
\hline Thalassiosira bulbosa Syvertsen & 0.0 & - & 0.0 & - & - & - \\
\hline Thalassiosira bulbosa Syvertsen resting spores & 0.4 & 1.2 & 0.8 & 0.6 & - & 0.3 \\
\hline Thalassiosira eccentrica (Ehrenberg) Cleve & - & - & 0.0 & 0.0 & - & - \\
\hline Thalassiosira gravida Cleve & 0.0 & - & 0.0 & - & - & 0.9 \\
\hline Thalassiosira hyalina (Grunow) Gran & 0.0 & 0.9 & 0.7 & 0.5 & 2.8 & 6.1 \\
\hline Thalassiosira hyperborea (Grunow) Hasle & - & - & - & 0.1 & - & - \\
\hline Thalassiosira kushirensis Takano resting spores & 0.2 & 0.4 & 0.0 & 0.4 & - & 2.6 \\
\hline Thalassiosira nordenskioeldii Cleve & 0.1 & 0.7 & 4.4 & 0.2 & 1.6 & 5.0 \\
\hline Thalassiosira pacifica Gran and Angst & 0.0 & 0.0 & 0.2 & - & - & - \\
\hline Thalassiosira punctigera (Castracane) Hasle & 0.0 & - & 0.4 & 0.0 & - & 0.6 \\
\hline Thalassiosira spp. & 0.2 & 3.1 & 1.9 & 0.6 & 1.6 & 0.9 \\
\hline Thalassiothrix longissima Cleve and Grunow & 0.0 & 0.4 & 0.0 & 0.1 & - & 1.8 \\
\hline Genus indet. & 0.5 & - & 0.1 & 0.5 & - & 4.4 \\
\hline
\end{tabular}



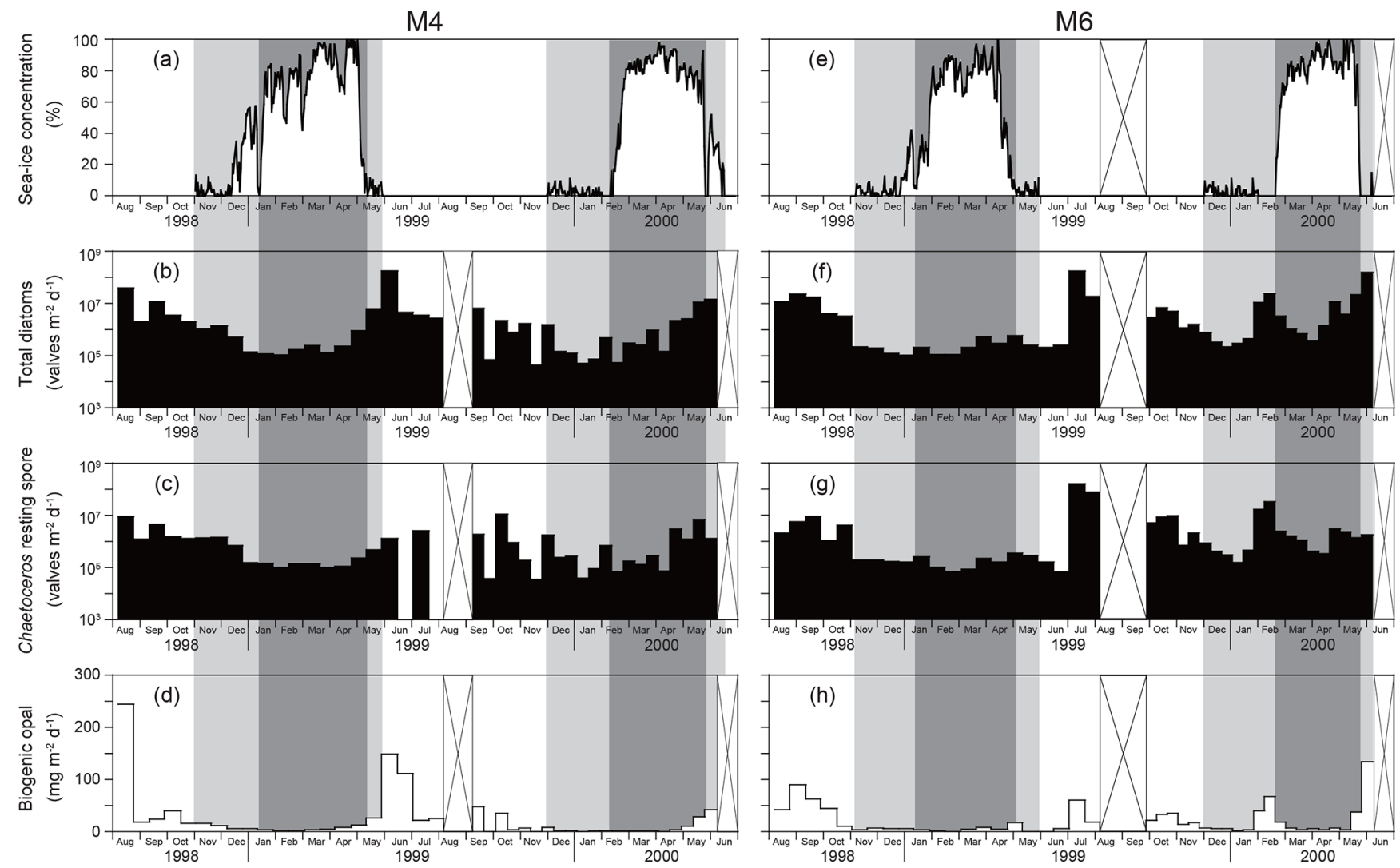

Figure 2. Temporal changes in (a) sea-ice concentrations at station M4 during 1998-2000 (Nakatsuka et al., 2004). Time-series fluxes of (b) total diatoms except for Chaetoceros resting spores, (c) Chaetoceros resting spores, and (d) biogenic opal (Nakatsuka et al., 2004) at station M4 during 1998-2000. Temporal changes in (e) sea-ice concentrations and time-series fluxes of (f) total diatoms, (g) Chaetoceros resting spores, and (h) biogenic opal (Nakatsuka et al., 2004) at station M6 during 1998-2000. Gray and dark gray areas denote stages of sea-ice coverage (see text). Areas with cross marks indicate periods without sediment-trap deployment.

\section{Discussion}

\subsection{Seasonal changes in diatom assemblages}

At sediment-trap stations M4 and M6 deployed off Sakhalin, the diatom fluxes showed pronounced seasonal changes that were closely related to seasonal sea-ice coverage (Fig. 2). The highest diatom fluxes were recorded during spring blooms after sea-ice retreat. In seasonally sea-ice-covered regions, the spring diatom bloom usually occurs at the ice edge because sea-ice melting produces a stratified water mass where diatoms readily remain in the euphotic zone (Niebauer et al., 1995; Katsuki and Takahashi, 2005). The spring diatom blooms during May to July at stations M4 and M6 were a few months later than those at station SA in the subarctic Pacific and at station $\mathrm{AB}$ in the Bering Sea (Onodera et al., 2005; Onodera and Takahashi, 2009). Both stations SA and AB are located in areas that are free of sea ice throughout the year. Sea-ice coverage must have influenced the spring bloom timings. In 1999, the spring diatom bloom at station M4 $\left(53^{\circ} \mathrm{N}\right)$ began soon after sea-ice retreat, whereas the spring diatom bloom at $\mathrm{M} 6\left(49.5^{\circ} \mathrm{N}\right)$ began 1 month after sea-ice retreat.
Nakatsuka et al. (2004) explained the southward propagation of the spring diatom bloom regardless of the northward sea-ice retreat as having to do with water mass stability. At station M4, a stable pycnocline could more easily be formed than at station M6 because of the freshwater supply from seaice melting. In addition, the surface salinity at M4 is generally lower than that at M6 because M4 is closer to the Amur River mouth.

During the spring blooms, Fragilariopsis cylindrus was the prevailing species in the diatom assemblages at both station M4 and station M6, although the fluxes of most of the diatom species also increased (Fig. 3). Fragilariopsis cylindrus is a representative diatom species in Antarctic marginal ice-edge zones (Kang and Fryxell, 1992; Gersonde and Zielinski, 2000) and the Arctic Ocean (Hasle, 1976; Cremer, 1999). However, von Quillfeldt (2004) discussed Fragilariopsis cylindrus as an indicator of cold water rather than sea ice. The flux of Chaetoceros resting spores also increased during the ice-melting stage. High abundances of Chaetoceros resting spores in surface sediments have been reported in the coastal and marginal areas of the subarctic Pacific, 

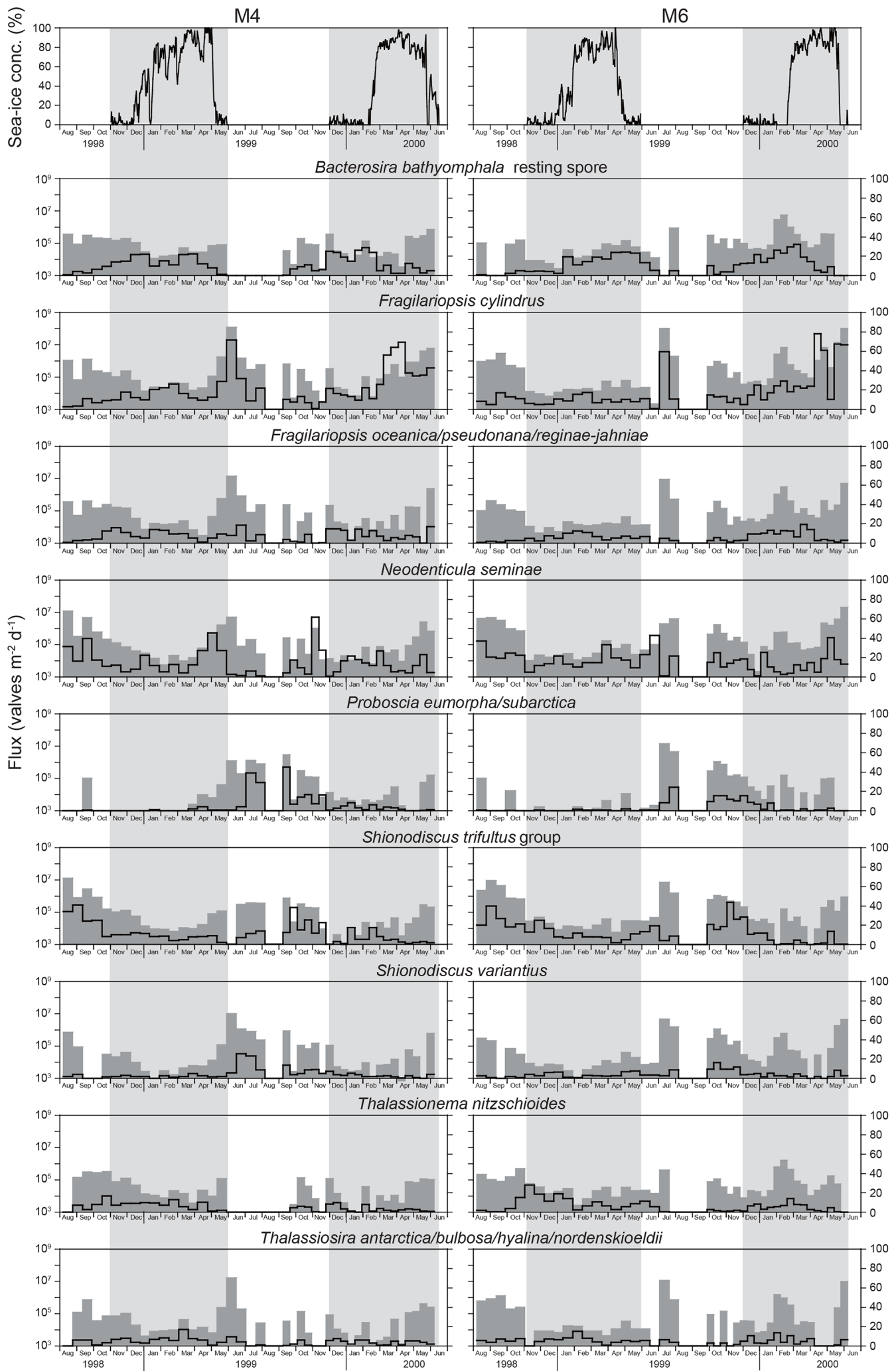

Figure 3. Temporal changes in sea-ice concentrations at stations M4 and M6 during 1998-2000 (Nakatsuka et al., 2004). Time-series fluxes (shaded graphs) and relative abundances (line graphs) of major diatom taxa at stations M4 and M6 during 1998-2000. Note that the relative abundances of diatom taxa were calculated excluding Chaetoceros resting spores. Vertical bars in light gray are periods with sea ice, identified on the basis of sea-ice concentrations greater than zero. Areas with cross marks indicate periods without sediment-trap deployment. 
including the Sea of Okhotsk (Sancetta, 1982; Ren et al., 2014); thus, this taxon has been suggested as an indicator of high primary productivity (Sancetta, 1982).

Fall diatom blooms were observed at stations M4 and M6 but with flux peaks approximately 1 order of magnitude lower than the spring peaks (Fig. 2). A similar trend was observed for chlorophyll- $a$ concentrations in the western Sea of Okhotsk (Nakatsuka et al., 2004). However, the opal flux peaks in spring and fall were approximately comparable despite the large interannual variability (Fig. 2). This discrepancy is mainly caused by the difference in diatom assemblages between the spring and fall blooms. Neodenticula seminae and the Shionodiscus trifultus group were major diatom taxa in the fall blooms. Both taxa are open-water taxa abundant in the western subarctic Pacific and the Bering Sea (Takahashi, 1986; Onodera et al., 2005; Shimada et al., 2006; Onodera and Takahashi, 2009). Their heavily silicified valves contributed to high opal fluxes in fall, whereas F. cylindrus, the prevailing diatom species in spring blooms, has small, thin valves that formed a lesser contribution to the opal flux. Considerably high fluxes of Chaetoceros resting spores were also observed at stations M4 and M6 in fall, indicating high productivity in the western Sea of Okhotsk off Sakhalin (Fig. 3). Nakatsuka et al. (2004) suggested that the Amur River discharge peak in September (Ogi et al., 2001) regulates the physical oceanographic conditions and silicate supply off Sakhalin. In September, low-salinity water flows southward from the Amur River mouth along the east coast of Sakhalin (Nakatsuka et al., 2004; Fujisaki et al., 2014). Indeed, significantly high primary productivity was observed in the estuary of the Amur River and the coastal area of Sakhalin during late summer (Isada et al., 2013). The increased Amur River discharge would have supplied silicaterich surface water to the area off Sakhalin and would have led to enhanced productivity of heavily silicified diatoms such as $N$. seminae and the $S$. trifultus group.

Diatom fluxes were low at stations M4 and M6 under seaice coverage (Fig. 2). During the early sea-ice cover stage with low sea-ice concentrations, the relative abundance of Bacterosira bathyomphala resting spores increased. The relative abundances of open-water taxa such as $N$. seminae and the $S$. trifultus group were still high, suggesting an exchange of surface water with the open ocean. During the maximum sea-ice cover stage with peak sea-ice concentrations, F. cylindrus and Bacterosira bathyomphala resting spores were the major diatom taxa. Even during the maximum seaice cover stage, $N$. seminae, an open-water diatom species, made a considerable contribution to the diatom assemblages in sinking-particle samples.

\subsection{Ice-related diatom species}

Diatom species in the Sea of Okhotsk that are proposed to be ice-related taxa in previous paleoceanographic studies (Shiga and Koizumi, 2000; Koizumi et al., 2003; Shimada et al.,
2004; Okazaki et al., 2005; Gorbarenko et al., 2007; Katsuki et al., 2010) are listed in Table 3. All these previous studies noted that three diatom species are ice-related: F. cylindrus, $F$. oceanica, and B. bathyomphala resting spores. Thalassiosira antarctica has also been categorized as an ice-related species, except by Shimada et al. (2004). Thalassiosira nordenskioeldii was suggested as being an ice-related species by Shiga and Koizumi (2000), Koizumi et al. (2003), and Katsuki et al. (2010). Only Gorbarenko et al. (2007) proposed that Thalassiosira gravida was an ice-related species, though they provided no taxonomic information.

In the Basket 6-2 sea-ice sample obtained near the Hokkaido coast on 28 February 2013, F. cylindrus was the dominant diatom species, accounting for $87 \%$ of the total diatom assemblage (Table 2). Note that this value is from snapshot data, and the sampling period and location are different from those of sediment-trap stations M4 and M6; hence, we are unable to compare this result directly with diatom assemblage data from sediment-trap samples. Instead, the dominance of $F$. cylindrus in the Basket 6-2 sea-ice sample merely indicates that $F$. cylindrus can survive in sea ice in the Sea of Okhotsk. In fact, reported major diatom taxa in sea-ice samples from lagoons and coastal areas of the Sea of Okhotsk are highly variable, e.g., Fragilaria spp. and Navicula spp. in the Notoro-ko Lagoon (Asami and Imada, 2001), Odontella aurita in the Saroma-ko Lagoon, and Thalassiosira nordenskioeldii along the Hokkaido coast (McMinn et al., 2008). Ice-algal diatoms flourish in brine pockets of high-salinity water trapped in sea ice. The physical properties of brine pockets are completely different from those of the surface water: low-light conditions, high salinity (40\%o to $63 \%$ ), and low temperature $\left(-3.4\right.$ to $-2.1^{\circ} \mathrm{C}$; Papadimitriou et al., 2007). Limited numbers of diatom species are adapted to this extreme environment; of these taxa, Fragilariopsis cylindrus, a colonial diatom species, is representative. In the darkness, F. cylindrus can metabolize using chrysolaminarin and fatty acid (Mock et al., 2017). Furthermore, F. cylindrus can secrete an antifreeze protein to impede brine pocket discharge (Bayer-Giraldi et al., 2011). These features are favorable for inhabiting sea ice, and $F$. cylindrus makes up the dominant proportion of diatom assemblages in sea ice. The presence of long chain colonies of $F$. cylindrus suggests rapid and repeated asexual reproduction in sea ice (Plate S3; Fig. 16). During sea-ice melting, $F$. cylindrus cells are released from sea ice and form the spring bloom.

Fragilariopsis oceanica/pseudonana/reginae-jahniae showed flux patterns similar to those of $F$. cylindrus at both M4 and M6 (Fig. 3); however, F. cylindrus was present in the Basket 6-2 sea-ice sample but Fragilariopsis oceanica/pseudonana/reginae-jahniae were not (Table 2). Common occurrences of $F$. oceanica and F. pseudonana have been reported in cold-water regions of the Arctic Ocean, subarctic Atlantic, and subarctic Pacific (Hasle et al., 1996; Sukhanova et al., 2009; Poulin et al., 2011; Ren et al., 2014). Fragilariopsis oceanica has been found in sea ice in the 


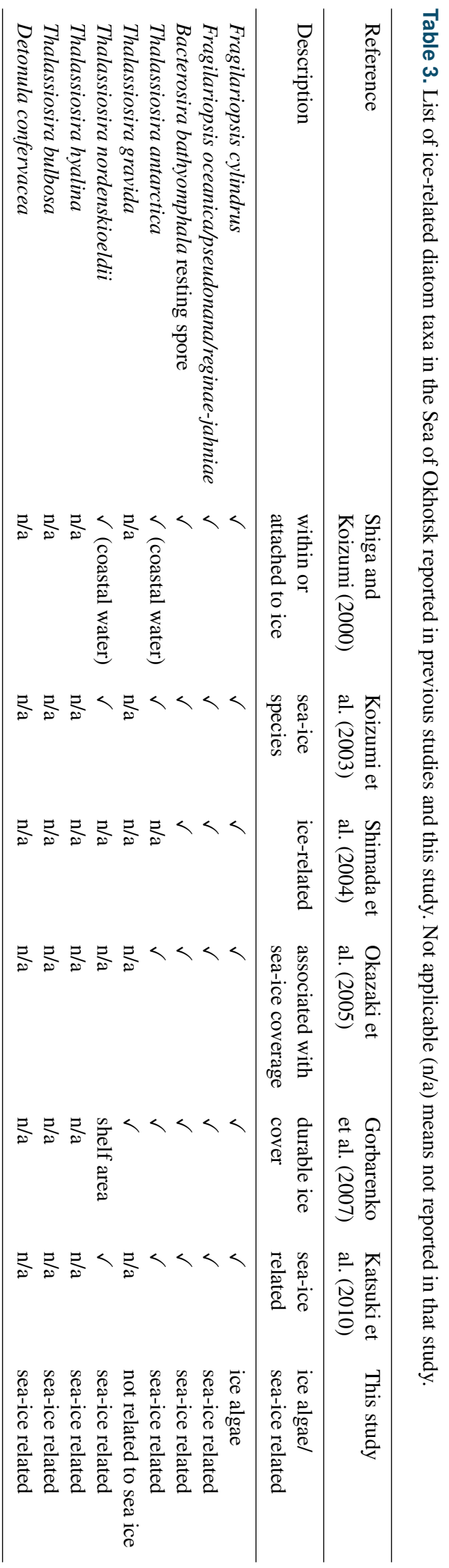

marginal Arctic Ocean (Ambrose et al., 2005; Poulin et al., 2011). Fragilariopsis pseudonana colonies have also been detected in sea ice in the Southern Ocean near Antarctica (Cefarelli et al., 2010). We suspect that the absence of Fragilariopsis oceanica/pseudonana/reginae-jahniae in the Basket 6-2 sea-ice sample was the result of interspecific competition in the extreme environment of brine pockets. In addition, Asami and Imada (2001) and McMinn et al. (2008) did not report $F$. oceanica, $F$. pseudonana, and $F$. reginaejahniae in their sea-ice samples. Considering their absence in sea-ice samples and the similarity of their flux patterns to those of F. cylindrus, we suggest that Fragilariopsis oceanica/pseudonana/reginae-jahniae are sea-ice-related diatom taxa in the Sea of Okhotsk.

Unlike F. cylindrus, resting spores of B. bathyomphala, the other representative sea-ice-related diatom species in the Sea of Okhotsk, were not found in the Basket 6-2 sea-ice sample. Similar results were observed in first-year ice samples (von Quillfeldt et al., 2003). Bacterosira bathyomphala (resting spores) is a minor diatom species in sea ice but the major diatom species in water around sea ice (von Quillfeldt et al., 2003). As B. bathyomphala resting spores are restricted to coastal waters (Hasle, 1973), these resting spores are associated with neritic cold water around sea ice.

We selected the following centric diatom species as potential ice-related species: Thalassiosira antarctica, T. bulbosa, T. hyalina, T. nordenskioeldii, and Detonula confervacea (Table 3). Of these, T. hyalina and T. nordenskioeldii were found in the Basket 6-2 sea-ice sample. Thalassiosira antarctica is a bipolar species that dwells mainly in neritic cold water (Hasle and Heimdal, 1968; Hasle, 1976) and has been regarded as an ice-related species associated with meltwater on sea-ice margins (Villareal and Fryxell, 1983; Pike et al., 2009). Thalassiosira antarctica forms resting spores, which are well preserved in sediment because they are heavily silicified (Cremer, 1999); however, in this study, T. antarctica resting spores were not encountered. Thalassiosira hyalina has not been reported in previous studies of diatom assemblages in the Sea of Okhotsk. The morphology of $T$. hyalina is similar to that of T. antarctica: T. antarctica has two rings of marginal spines and T. hyalina has one ring. These rings of spines are often barely distinguishable under the light microscope (Hasle and Heimdal, 1968). Because all previous studies in the Sea of Okhotsk were conducted by means of light microscopy, $T$. hyalina might have been confused with $T$. antarctica. Thalassiosira gravida is a bipolar species (Hasle, 1976). In the Southern Ocean, T. gravida often appears in open water and is very rare in sea ice (Fryxell and Kendrick, 1988). In the Arctic Ocean, T. gravida occurs in temperate to cold waters (Katsuki et al., 2009; Poulin et al., 2011). In addition, $T$. gravida is predominant in Kongsfjorden, Svalbard, in July, at a time without sea-ice coverage (Hasle and Heimdal, 1998). These findings suggest that $T$. gravida is not a typical ice-algal diatom species, and we exclude this species from sea-ice-related species. In the Arctic Ocean, Thalassiosira 
nordenskioeldii is a major diatom species of the spring bloom (Eilertsen et al., 1989; Sommer and Lewandowska, 2011) and is abundant in summer shallow water (Tuschling et al., 2000); however, T. nordenskioeldii has not been reported in Arctic sea-ice samples (Cremer, 1999). Unlike in the Arctic Ocean, in this study the relative abundances of $T$. nordenskioeldii were less than $5 \%$ in both sea-ice and sedimenttrap samples. Detonula confervacea and Thalassiosira bulbosa have not been reported in previous studies in the Sea of Okhotsk, but these two species have been observed in neritic cold water around sea ice in the Arctic Ocean (Karentz and Smayda, 1984; Syvertsen and Hasle, 1984).

We have identified ice-algal diatoms in the Sea of Okhotsk and divided them into two groups: (1) F. cylindrus, an ice alga living in sea ice; and (2) sea-ice-related diatoms living in neritic cold water associated with sea ice (B. bathyomphala resting spores, F. oceanica/pseudonana/reginae-jahniae, $T$. antarctica, T. nordenskioeldii, T. hyalina, D. confervacea, and T. bulbosa).

\subsection{Comparison of diatom assemblages between sinking-particle and surface-sediment samples}

The species compositions of diatom assemblages showed obvious differences between sinking-particle (M6) and surfacesediment (XP98-MC4) samples obtained at adjacent locations off Sakhalin (Fig. 4). Because the XP98-MC4 core was obtained in July 1998 prior to the deployment of sediment trap M6 (deployed August 1998 to June 2000), sinking particles trapped at M6 were not included in the XP98-MC4 core sample. In addition, the core-top sample of XP98-MC4 represents an $\sim 35$-year record, as noted in Sect. 3.3. Therefore, differences in the diatom species compositions of sedimenttrap and surface-sediment samples should be due to selective preservation of diatom species during sinking and sedimentation. Diatom frustules are made of biogenic opal, which can be broken/dissolved by both physical and chemical processes. Physical processes include feeding by zooplankton and benthos, tidal mixing, and turbidites. Chemical processes consist of dissolution in seawater and pore water. To prevent chemical dissolution, living diatom cells form an organic casing called a capsule outside of their frustules (Armbrust et al., 2004). When diatoms are dead, their frustules are exposed to seawater and pore water, accelerating chemical dissolution (Kamatani and Riley, 1979; Shemesh et al., 1989; Nelson et al., 1995). The dissolution/preservation of diatom frustules differ markedly between species depending on the structure, thickness, and surface area of the valves (Leventer, 1998; Ryves et al., 2001; Shimada et al., 2003).

In this study, some diatom taxa showed markedly higher relative abundances in the surface-sediment sample than in the sinking-particle samples: $B$. bathyomphala resting spores, neritic cold diatoms (T. antarctica, T. nordenskioeldii, T. hyalina, D. confervacea, and T. bulbosa), Shionodiscus variantius, and Thalassionema nitzschioides. In con- trast, some diatom taxa showed obviously lower relative abundances in the surface-sediment sample than in sinkingparticle samples: Fragilariopsis cylindrus and Proboscia eumorpha/subarctica. The diatoms of the group with higher relative abundances in the sediment sample have relatively thick silicified valves compared to the other group. In general, thin valves are fragile and easily damaged. Once a valve is damaged, the increased surface area leads to more chemical dissolution (Kamatani and Riley, 1979). Fragilariopsis cylindrus is a typical thin-valved species of the diatom taxa encountered in this study. In the case of P. eumorpha/subarctica, the valves are not as thin, but the girdles are very thin; hence, their frustules readily become separated. In fact, all $P$. eumorpha/subarctica specimens encountered during microscopic observations of the XP98-MC4 surfacesediment sample were valves and fragments. The fine structure of diatom frustules may also affect their preservation. For instance, punctae (fine pores on the valve surface) and areolae (coarse pores on the valve surface) act as a path for seawater. Shimada et al. (2003) demonstrated that faster dissolution occurs on the valve of $N$. seminae than on the copula. As dissolution progresses, the punctae on $N$. seminae valves increase in diameter and become connected to each other (Shimada et al., 2003). In this study, there is a considerable difference in the preservation of the $S$. trifultus group and that of $S$. variantius. Both species belong to the genus Shionodiscus and have a basically similar morphology except for the presence of a velum, a thin siliceous structure covering the areolae on the external side (Plate S2). The S. trifultus group has no velum, whereas $S$. variantius possesses a velum (Shiono, 2001). Better preservation of $S$. variantius in sediment might be because of the presence of a velum, which prevents seawater infiltration. A similar structure covering the areolae is also found in Thalassionema nitzschioides (Plate S3). Good preservation of $T$. nitzschioides in sediment is consistent with the hypothesis that the presence of a siliceous structure covering the areolae plays an important role in the preservation of diatom frustules.

\section{Conclusions}

We investigated diatom assemblages in sea-ice, sinkingparticle, and surface-sediment samples in the Sea of Okhotsk by means of SEM. Ten diatom taxa were identified in a seaice sample collected from the southwestern Sea of Okhotsk near the Hokkaido coast in February 2013. Fragilariopsis cylindrus was the dominant diatom species in the sea-ice sample, making up $87 \%$ of the total diatom assemblage. Time-series sediment traps were deployed at two stations, M4 and M6, off Sakhalin during 1998-2000. Total diatom fluxes ranged from $10^{5}$ to $10^{8}$ valves $\mathrm{m}^{-2} \mathrm{~d}^{-1}$ with pronounced summer peaks. During summer and fall, the Shionodiscus trifultus group and Neodenticula seminae were the major diatom taxa. In contrast, during the sea-ice cov- 


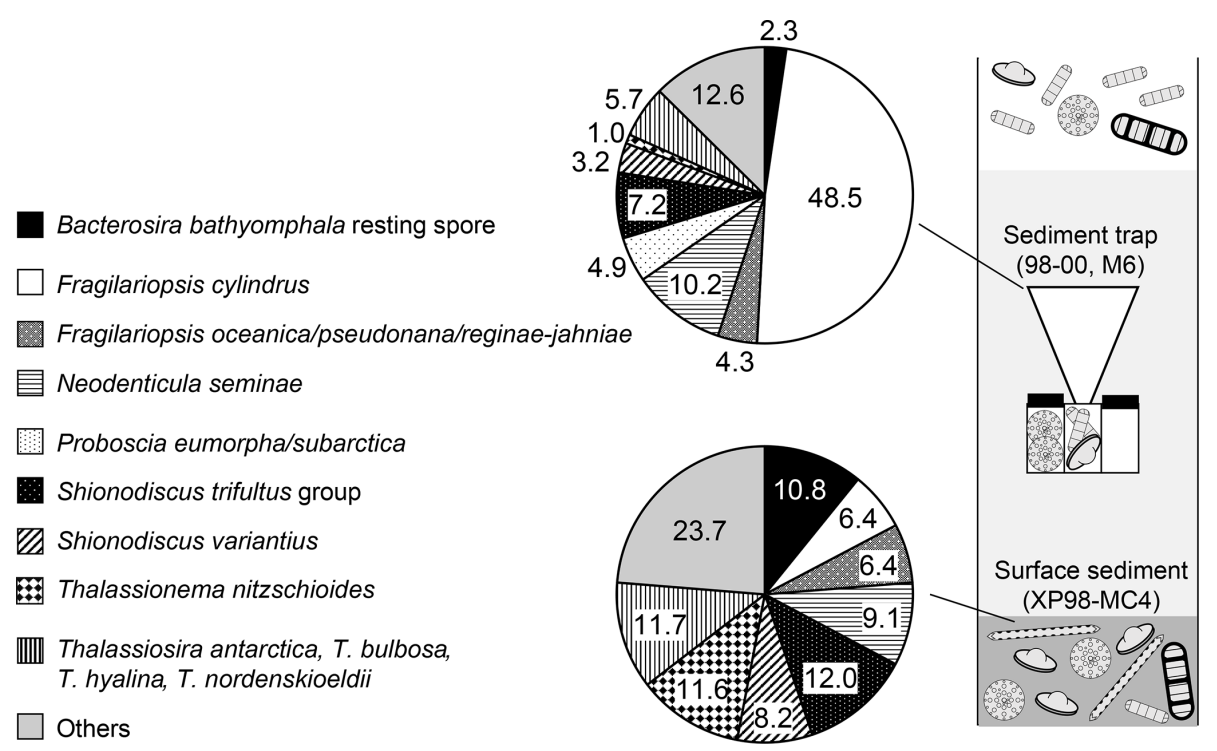

Figure 4. Comparison of the relative abundances of major diatom taxa in sediment-trap samples at station M6 (average between 1998 and 2000) and the surface-sediment sample of core XP98-MC4.

ering period, the total diatom flux decreased by 1 or 2 orders of magnitude. During the sea-ice covering period, Fragilariopsis cylindrus, F. oceanica/pseudonana/reginaejahniae, and Bacterosira bathyomphala resting spores were the major taxa. Fragilariopsis cylindrus fluxes exhibited pronounced spring bloom peaks of $10^{8}$ valves $\mathrm{m}^{-2} \mathrm{~d}^{-1}$; these diatoms were released from sea ice during sea-ice retreat. In addition, neritic cold diatoms ( $T$. antarctica, T. nordenskioeldii, T. hyalina, D. confervacea, and T. bulbosa) showed a relatively high contribution during the sea-ice covering period. These neritic cold diatoms were not living in sea ice but in neritic cold water associated with sea ice. The diatom species compositions of sediment-trap (M6) and surface-sediment (XP98-MC4) samples showed obvious differences depending on the diatom valve and girdle robustness. Heavily silicified diatom taxa such as B. bathyomphala resting spores, neritic cold diatoms, Shionodiscus variantius, and Thalassionema nitzschioides showed markedly higher relative abundances in surface-sediment samples than in sinking-particle samples. In contrast, the relative abundances of Fragilariopsis cylindrus and Proboscia eumorpha/subarctica were notably lower in surface-sediment samples than in sinking-particle samples.

Data availability. The data associated with this paper are available in Table 2 and the Supplement.

Supplement. The supplement related to this article is available online at: https://doi.org/10.5194/jm-39-77-2020-supplement.
Author contributions. The study was designed by YO. The samples were collected by TN. Sample preparation and SEM observations were performed by $\mathrm{HN}$ and SK. The article was written by $\mathrm{HN}$ and YO with contributions from SK and TN.

Competing interests. The authors declare that they have no conflict of interest.

Acknowledgements. We sincerely thank the scientists, technicians, captain, and crew of R/V Professor Khromov for their efforts in obtaining sediment-trap and sediment samples during cruises XP98, XP99, and XP00. Jun Nishioka of Hokkaido University provided a sea-ice sample collected during the SOYA2013 cruise of PLH Soya. Eisuke Araki of Kyushu University helped with sample preparation and taking SEM photographs of diatoms in sediment samples. Kazuhiko Shimada of Kyushu University supported FE-SEM operation. We also thank Tatsuya Hayashi of Kyushu University for his helpful suggestions on diatom taxonomy. We thank Oscar E. Romero and an anonymous reviewer for their thoughtful suggestions on improving the paper.

Financial support. This study was financially supported by a grant from the Core Research for Evolutional Science and Technology (CREST), Japanese Science and Technology Corporation, a grant for the joint research program of the Institute of Low Temperature Science, Hokkaido University, and KAKENHI 16H04069 and $17 \mathrm{H} 01617$.

Review statement. This paper was edited by Taniel Danelian and reviewed by Oscar E. Romero and one anonymous referee. 


\section{References}

Ambrose Jr., W. G., von Quillfeldt, C., Clough, L. M., Tilney, P. V. R., and Tucker, T.: The sub-ice algal community in the Chukchi sea: large- and small-scale patterns of abundance based on images from a remotely operated vehicle, Polar Biol., 28, 784-795, https://doi.org/10.1007/s00300-005-0002-8, 2005.

Armbrust, E. V., Berges, J. A., Bowler, C., Green, B. R., Martinez, D., Putnam, N. H., Zhou, S., Allen, A. E., Apt, K. E., Bechner, M., Brzezinski, M. A., Chaal, B. K., Chiovitti, A., Davis, A. K., Demarest, M. S., Detter, J. C., Glavina, T., Goodstein, D., Hadi, M. Z., Hellsten, U., Hildebrand, M., Jenkins, B. D., Jurka, J., Kapitonov, V. V., Kröger, N., Lau, W. W. Y., Lane, T. W., Larimer, F. W., Lippmeier, J. C., Lucas, S., Medina, M., Montsant, A., Obornik, M., Parker, M. S., Palenik, B., Pazour, G. J., Richardson, P. M., Rynearson, T. A., Saito, M. A., Schnwartz, D. C., Thamatrakoln, K., Valentin, K., Vardi, A., Wilkerson, F. P., and Rokhsar, D. S.: The genome of the diatom Thalassiosira Pseudonana: ecology, evolution, and metabolism, Science, 306, 79-86, https://doi.org/10.1126/science.1101156, 2004.

Artemova, A., Gorbarenko, S., Vasilenko, Y., Shi, X., Liu, Y., and Chen, M.-T.: Paleoceanography changes in the Okhotsk Sea during late Pleistocene and Holocene according to diatoms, Quaternary Int., 459, 175-186, https://doi.org/10.1016/j.quaint.2017.10.002 2017.

Asami, H. and Imada, K.: Ice algae and phytoplankton in the late ice-covered season in Notoro Ko lagoon, Hokkaido, Polar Biosci., 14, 24-32, 2001.

Bayer-Giraldi, M., Weikusat, I., Besir, H., and Dieckmann, G.: Characterization of an antifreeze protein from the polar diatom Fragilariopsis cylindrus and its relevance in sea ice, Cryobiology, 63, 210-219, https://doi.org/10.1016/j.cryobiol.2011.08.006, 2011.

Behrenfeld, M. J. and Falkowski, P. G.: Photosynthetic rates derived from satellite-based chlorophyll concentration, Limnol. Oceanogr., 42, 1-20, https://doi.org/10.4319/lo.1997.42.1.0001, 1997.

Belt, S. T. and Muller, J.: The Arctic sea ice biomarker IP25: a review of current understanding, recommendations for future research and applications in palaeo sea ice reconstructions, Quaternary Sci. Rev., 79, 9-25, https://doi.org/10.1016/j.quascirev.2012.12.001, 2013.

Belt, S. T., Massé, G., Rowland, S. J., Poulin, M., Michel, C., and LeBlanc, B.: A novel chemical fossil of palaeo sea ice: IP25, Org. Geochem., 38, 16-27, https://doi.org/10.1016/j.orggeochem.2006.09.013, 2007.

Cefarelli, A. O., Ferrario, M. E., Almandoz, G. O., Atencio, A. G., Akselman, R., and Vernet, M.: Diversity of the diatom genus Fragilariopsis in the Argentine Sea and Antarctic waters: morphology, distribution and abundance, Polar Biol., 33, 1463-1484, https://doi.org/10.1007/s00300-010-0794-z, 2010.

Cremer, H.: Distribution patterns of diatom surface sediment assemblages in the Laptev Sea (Arctic Ocean), Mar. Micropaleontol., 38, 39-67, https://doi.org/10.1016/S0377-8398(99)00037-7, 1999.

Dodimead, J., Favorite, F., and Hirano, T.: Review of oceanography of the subarctic Pacific region, Bull. Int. North Pacific Comm., 13, 1-195, 1963.
Eilertsen, H. C., Taasen, J. P., and Weslawski, J. M.: Phytoplankton studies in the fjords of West Spitzbergen: physical environment and production in spring and summer, J. Plankton Res., 11, 1245-1260, https://doi.org/10.1093/plankt/11.6.1245, 1989.

Favorite, F., Dodimead, A. J., and Nasu, K.: Oceanography of the subarctic Pacific region, 1960-71, Bull. Int. North Pacific Comm., 33, 1-187, 1976.

Fryxell, G. A. and Kendrick, G. A.: Austral spring microalgae across the Weddell Sea ice edge: spatial relationships found along a northward transect during AMERIEZ 83, Deep-Sea Res. Pt. A, 35, 1-20, https://doi.org/10.1016/0198-0149(88)90054-4, 1988.

Fujisaki, A., Mitsudera, H., Wang, J., and Wakatsuchi, M.: How does the Amur River discharge flow over the northwestern continental shelf in the Sea of Okhotsk?, Prog. Oceanogr., 126, 8-20, https://doi.org/10.1016/j.pocean.2014.04.028, 2014.

Gersonde, R. and Zielinski, U.: The reconstruction of late Quaternary Antarctic sea-ice distribution - the use of diatoms as a proxy for sea-ice, Palaeogeogr. Palaeocl., 162, 263-286, https://doi.org/10.1016/S0031-0182(00)00131-0, 2000.

Gorbarenko, S. A., Goldberg, E. L., Kashgarian, M., Velivetskaya, T. A., Zakharkov, S. P., Pechnikov, V. S., Bosin, A. A., Psheneva, O. Y., and Ivanova, E. D.: Millennium scale environment changes of the Okhotsk Sea during last $80 \mathrm{kyr}$ and their phase relationship with global climate changes, J. Oceanogr., 63, 609-623, https://doi.org/10.1007/s10872-007-0054-1, 2007.

Gorbarenko, S. A., Psheneva, O. Y., Artemova, A. V., Matul, A. G., Tiedemann, R., and Nürnberg, D.: Paleoenvironment changes in the NW Okhotsk Sea for the last 18 thousand years by micropaleontologic, geochemical, and lithological data, Deep-Sea Res. Pt I, 57, 797-811, https://doi.org/10.1016/j.dsr.2010.04.004, 2010.

Gorbarenko, S. A., Artemova, A. V., Goldberg, E. L., and Vasilenko, Y. P.: The response of the Okhotsk Sea environment to the orbital-millennium global climate changes during the last glacial maximum, deglaciation and Holocene, Global Planet. Change, 116, 76-90, https://doi.org/10.1016/j.gloplacha.2014.02.002, 2014.

Harada, N., Katsuki, K., Nakagawa, M., Matsumoto, A., Seki, O., Addison, J. A., Finney, B. P., and Sato, M.: Holocene sea surface temperature and sea ice extent in the Okhotsk and Bering Seas, Prog. Oceanogr. 126, 242-253, https://doi.org/10.1016/j.pocean.2014.04.017, 2014.

Hasle, G. R.: Some marine plankton genera of the diatom family Thalassiosiraceae, Beihefte zur Nova Hedwigia, 45, 1-49, 1973.

Hasle, G. R.: The biogeography of some marine planktonic diatoms, Deep-Sea Res., 23, 319-338, https://doi.org/10.1016/00117471(76)90873-1, 1976

Hasle, G. R. and Heimdal, B. R.: Morphology and distribution of the marine centric diatom Thalassiosira antarctica Comber, J. Roy. Microscopical Soc., 88, 357-369, https://doi.org/10.1111/j.1365-2818.1968.tb00618.x, 1968.

Hasle, G. R. and Heimdal, B. R.: The net phytoplankton in Kongsfjorden, July 1988, with general remarks on species composition of arctic phytoplankton, Polar Res., 17, 31-52, https://doi.org/10.3402/polar.v17i1.6605, 1998.

Hasle, G. R., Syvertsen, E. E., and von Quillfeldt, C. H.: Fossula Arctica gen nov., spec. nov., a marine Arctic araphid diatom, Diatom Res., 11, 261-272, https://doi.org/10.1080/0269249X.1996.9705383, 1996. 
Isada, T., Iida, T., Liu, H., Saitoh, S., Nishioka, J., Nakatsuka, T., and Suzuki, K.: Influence of Amur River discharge on phytoplankton photophysiology in the Sea of Okhotsk during late summer, J. Geophys. Res.-Oceans, 118, 1995-2013, https://doi.org/10.1002/jgrc.20159, 2013.

Itoh, M., Ohshima, K. I., and Wakatsuchi, M.: Distribution and formation of Okhotsk Sea Intermediate Water: An analysis of isopycnal climatological data, J. Geophys. Res., 108, 3258, https://doi.org/10.1029/2002JC001590, 2003.

Japan Meteorological Agency: Sea ice in the Sea of Okhotsk, available at: http://www.data.jma.go.jp/gmd/kaiyou/english/seaice_ okhotsk/series_okhotsk_e.html (last access: 2 June 2020), 2017.

Kamatani, A. and Riley, J. P.: Rate of dissolution of diatom silica walls in seawater, Mar. Biol., 55, 29-35, https://doi.org/10.1007/BF00391714, 1979.

Kang, S.-H. and Fryxell, G. A.: Fragilariopsis cylindrus (Grunow) Krieger: the most abundant diatom in water column assemblages of Antarctic marginal ice-edge zones, Polar Biol., 12, 609-627, https://doi.org/10.1007/BF00236984, 1992.

Karentz, D. and Smayda, T. J.: Temperature and seasonal occurrence patterns of 30 dominant phytoplankton species in Narragansett Bay over a 22-year period (1959-1980), Mar. Ecol.-Prog. Ser., 18, 277-293, 1984.

Kashiwase, H., Ohshima, K. I., and Nihashi, S.: Long-term variation in sea ice production and its relation to the intermediate water in the Sea of Okhotsk, Prog. Oceanogr., 126, 21-32, https://doi.org/10.1016/j.pocean.2014.05.004, 2014.

Katsuki, K. and Takahashi, K.: Diatom as paleoenvironmental proxies for seasonal productivity, sea-ice and surface circulation in the Bering Sea during the late Quaternary, Deep-Sea Res. Pt. II, 52, 2110-2130, https://doi.org/10.1016/j.dsr2.2005.07.001, 2005.

Katsuki, K., Takahashi, K., Onodera, J., Jordan, R. W., and Suto, I.: Living diatoms in the vicinity of the North Pole, summer 2004, Micropaleontology, 55, 137-170, 2009.

Katsuki, K., Khim, B.-K., Itaki, T., Okazaki, Y., Ikehara, K., Shin, Y., Yoon, H. I., and Kang, C. Y.: Sea ice distribution and atmospheric pressure patterns in southwestern Okhotsk Sea since the Last Glacial Maximum, Global Planet. Change, 72, 99-107, https://doi.org/10.1016/j.gloplacha.2009.12.005, 2010.

Kimura, N. and Wakatsuchi, M.: Increase and decrease of sea ice area in Sea of Okhotsk: Ice production in coastal polynyas and dynamic thickening in convergence zones, J. Geophys. Res., 109, C09S03, https://doi.org/10.1029/2003JC001901, 2004.

Koizumi, I., Shiga, K., Irino, T., and Ikehara, M.: Diatom record of the Holocene in the Okhotsk Sea, Mar. Micropaleontol., 49, 139156, https://doi.org/10.1016/S0377-8398(03)00033-1, 2003.

Leventer, A.: The fate of Antarctic "sea ice diatoms" and their use as paleoenvironmental indicators, in: Antarctic Sea Ice: Biological Processes, Interactions and Variability, edited by: Lizotte, M. P. and Arrigo, K. R., Antarctic Research Series, 73, AGU, USA, 121-137, https://doi.org/10.1029/AR073p0121, 1998.

Lo, L., Belt, S. T., Lattaud, J., Friedrich, T., Zeeden, C., Schouten, S., Smik, L., Timmermann, A., Cabedo-Sanz, P., Huang, J.J., Zhou, L., Ou, T.-H., Chang, Y.-P., Wang, L.-C., Chou, Y.M., Shen, C.-C., Chen, M.-T., Wei, K.-Y., Song, S.-R., Fang, T.-H., Gorbarenko, S. A., Wang, W.-L., Lee, T.-Q., Elderfield, H., and Hodell, D. A.: Precession and atmospheric $\mathrm{CO}_{2}$ modulated variability of sea ice in the central Okhotsk Sea since 130,000 years ago, Earth Planet. Sc. Lett., 488, 36-45, https://doi.org/10.1016/j.epsl.2018.02.005, 2018.

Martin, S., Drucker, R., and Yamashita, K.: The production of ice and dense shelf water in the Okhotsk Sea polynyas, J. Geophys. Res., 103, 27771-27782, https://doi.org/10.1029/98JC02242, 1998.

Matsumoto, C., Saitoh, S., Takahashi, F., and Wakatsuchi, M.: Use of multi-sensor remote sensing to detect seasonal and interannual variability in chlorophyll a distribution in the Sea of Okhotsk, Proc. 3rd workshop on the Okhotsk Sea and Adjacent areas, PICES Sci. Rep., 26, 151-157, 2004.

Matul, A. G.: Probable limits of sea ice extent in the northwestern subarctic Pacific during the last glacial maximum, Oceanology, 57, 700-706, https://doi.org/10.1134/S0001437017050113, 2017.

McMinn, A., Hattori, H., Hirawake, T., and Iwamoto, A.: Preliminary investigation of Okhotsk Sea ice algae; taxonomic composition and photosynthetic activity, Polar Biol., 31, 1011-1015, https://doi.org/10.1007/s00300-008-0433-0, 2008.

Mock, T., Otillar, R. P., Strauss, J., McMullan, M., Paajanen, P., Schmutz, J., Salamov, A., Sanges, R., Toseland, A., Ward, B. J., Allen, A. E., Dupont, C. L., Frickenhaus, S., Maumus, F., Veluchamy, A., Wu, T., Barry, K. W., Falciatore, A., Ferrante, M. I., Fortunato, A. E., Glöckner, G, Gruber, A., Hipkin, R., Janech, M. G., Kroth, P. G., Leese, F., Lindquist, E. A., Lyon, B. R., Martin, J., Mayer, C., Parker, M., Quesneville, H., Raymond, J. A., Uhlig, C., Valas, R. E., Valentin, K. U., Worden, A. Z., Armbrust, E. V., Clark, M. D., Bowler, C., Green, B. R., Moulton, V., van Oosterhout, C., and Grigoriev, I. V.: Evolutionary genomics of the cold-adapted diatom Fragilariopsis cylindrus, Nature, 541, 536-540, https://doi.org/10.1038/nature20803, 2017.

Nakanowatari, T., Ohshima, K. I., and Wakatsuchi, M.: Warming and oxygen decrease of intermediate water in the northwestern North Pacific, originating from the Sea of Okhotsk, 1955-2004, Geophys. Res. Lett., 34, L04602, https://doi.org/10.1029/2006GL028243, 2007.

Nakatsuka, T., Fujimune, T., Yoshikawa, C., Noriki, S., Kawamura, K., Fukamachi, Y., Mizuta, G., and Wakatsuchi, M.: Biogenic and lithogenic particle fluxes in the western region of the Sea of Okhotsk: Implications for lateral material transport and biological productivity, J. Geophys. Res., 109, C09S13, https://doi.org/10.1029/2003JC001908, 2004.

Nelson, D. M., Tréguer, P., Brzezinski, M. A., Leynaert, A., and Quéguiner, B.: Production and dissolution of biogenic silica in the ocean: Revised global estimates, comparison with regional data and relationship to biogenic sediment, Global Biogeochem. Cy., 9, 359-372, https://doi.org/10.1029/95GB01070, 1995.

Niebauer, H. J., Alexander, V., and Henrichs, S. M.: A time-series of the spring bloom at the Bering Sea ice edge: I. Physical processes, chlorophyll and nutrient chemistry, Cont. Shelf Res., 15, 1859-1877, https://doi.org/10.1016/0278-4343(94)00097-7, 1995.

Nürnberg, D. and Tiedemann, R.: Environmental change in the Sea of Okhotsk during the last 1.1 million years, Paleoceanography, 19, PA4011, https://doi.org/10.1029/2004PA001023, 2004.

Nürnberg, D., Dethleff, D., Tiedemann, R., Kaiser, A., and Gorbarenko, S. A.: Okhotsk Sea ice coverage and Kamchatka glaciation over the last $350 \mathrm{ka}$ - evidence from ice-rafted de- 
bris and planktonic $\delta^{18} \mathrm{O}$, Palaeogeogr. Palaeocl., 310, 191-205, https://doi.org/10.1016/j.palaeo.2011.07.011, 2011.

Ohshima, K. I., Wakatsuchi, M., Fukamachi, Y., and Mizuta, G.: Near-surface circulation and tidal currents of the Okhotsk Sea observed with satellite-tracked drifters, J. Geophys. Res., 107, 3195, https://doi.org/10.1029/2001JC001005, 2002

Ohshima, K. I, Nihashi, S., Hashiya, E., and Watanabe, T.: Interannual variability of sea ice area in the Sea of Okhotsk: Importance of surface heat flux in fall, J. Meteorol. Soc. Jpn., 84, 907-919, https://doi.org/10.2151/jmsj.84.907, 2006.

Ogi, M., Tachibana, Y., Nishio, F., and Danchenkov, M. A.: Does the fresh water supply from the Amur river flowing into the Sea of Okhotsk affect sea ice formation?, J. Meteorol. Soc. Jpn., 79, 123-129, https://doi.org/10.2151/jmsj.79.123, 2001.

Okazaki, Y., Takahashi, K., Yoshitani, H., Nakatsuka, T., Ikehara, M., and Wakatsuchi, M.: Radiolarians under the seasonally seaice covered conditions in the Okhotsk Sea: flux and their implications for paleoceanography, Mar. Micropaleontol., 49, 195-230, https://doi.org/10.1016/S0377-8398(03)00037-9, 2003.

Okazaki, Y., Takahashi, K., Katsuki, K., Ono, A., Hori, J., Sakamoto, T., Uchida, M., Shibata, Y., Ikehara, M., and Aoki, K.: Late Quaternary Paleoceanographic changes in the southwestern Okhotsk Sea: evidence from geochemical, radiolarian, and diatom records, Deep-Sea Res. Pt. II, 52, 2332-2350, https://doi.org/10.1016/j.dsr2.2005.07.007, 2005.

Onodera, J. and Takahashi, K.: Long-term diatom fluxes in response to oceanographic conditions at Station $\mathrm{AB}$ and $\mathrm{SA}$ in the central subarctic Pacific and the Bering Sea, 1990-1998, Deep-Sea Res. Pt. I, 156, 189-211, https://doi.org/10.1016/j.dsr.2008.08.006, 2009.

Onodera, J., Takahashi, K., and Honda, M. C.: Pelagic and coastal diatom fluxes and the environmental changes in the northwestern North Pacific during December 1997-May 2000, Deep-Sea Res. Pt. II, 52, 2218-2239, https://doi.org/10.1016/j.dsr2.2005.07.005, 2005.

Papadimitriou, S., Thomas, D. N., Kennedy, H., Hass, C., Kuosa, H., Krell, A., and Dieckmann, G. S.: Biogeochemical composition of natural sea ice brines from the Weddell Sea during early austral summer, Limnol. Oceanogr., 52, 1809-1823, https://doi.org/10.4319/lo.2007.52.5.1809, 2007.

Pike, J., Crosta, X., Maddison, E. J., Stickley, C. E., Denis, D., Barbara, L., and Renssen, H.: Observations on the relationship between the Antarctic coastal diatoms Thalassiosira antarctica Comber and Porosira glacialis (Grunow) Jørgensen and sea ice concentrations during the late Quaternary, Mar. Micropaleontol., 73, 14-25, https://doi.org/10.1016/j.marmicro.2009.06.005, 2009.

Poulin, M., Daugbjerg, N., Gradinger, R., Ilyash, L., Ratkova, T., and von Quillfeldt, C.: The pan-Arctic biodiversity of marine pelagic and sea-ice unicellular eukaryotes: a first-attempt assessment, Mar. Biodivers., 41, 13-28, https://doi.org/10.1007/s12526-010-0058-8, 2011.

Ren, J., Gersonde, R., Esper, O., and Sancetta, C: Diatom distributions in northern North Pacific surface sediments and their relationship to modern environmental variables, Palaeogeogr. Palaeocl., 402, 81-103, https://doi.org/10.1016/j.palaeo.2014.03.008, 2014.

Ryves, D. B., Juggins, S., Fritz, S. C., and Battarbee, R. W.: Experimental diatom dissolution and the quantification of microfossil preservation in sediments, Palaeogeogr. Palaeocl., 172, 99-113, https://doi.org/10.1016/S0031-0182(01)00273-5, 2001.

Saitoh, S., Kishino, M., Kiyofuji, H., Taguchi, S., and Takahashi, M.: Seasonal variability of phytoplankton pigment concentration in the Okhotsk Sea, Bull. Remote Sensing Soc. Jpn., 16, 86-92, https://doi.org/10.11440/rssj1981.16.172, 1996.

Sakamoto, T., Ikehara, M., Aoki, K., Iijima, K., Kimura, N., Nakatsuka, T., and Watanabe, M.: Ice-rafted debris (IRD)based sea-ice expansion events during the past $100 \mathrm{kyrs}$ in the Okhotsk Sea, Deep-Sea Res. Pt. II, 52, 2275-2301, https://doi.org/10.1016/j.dsr2.2005.08.007, 2005.

Sakamoto, T., Ikehara, M., Uchida, M., Aoki, K., Shibata, Y., Kanamatsu, T., Harada, N., Iijima, K., Katsuki, K., Asahi, H., Takahashi, K., Sakai, H., and Kawahata, H.: Millennial-scale variations of sea-ice expansion in the southwestern part of the Okhotsk Sea during the past $120 \mathrm{kyr}$ : Age model and ice-rafted debris in IMAGES Core MD01-2412, Global Planet. Change, 53, 58-77, https://doi.org/10.1016/j.gloplacha.2006.01.012, 2006.

Sancetta, C.: Oceanographic and ecologic significance of diatoms in surface sediments of the Bering and Okhotsk seas, DeepSea Res. Pt. A, 28, 789-817, https://doi.org/10.1016/S01980149(81)80002-7, 1981.

Sancetta, C.: Distribution of diatom species in surface sediments of the Bering and Okhotsk seas, Micropaleontology, 28, 221-257, https://doi.org/10.2307/1485181, 1982.

Seki, O., Ikehara, M., Kawamura, K., Nakatsuka, T., Ohnishi, K., Wakatsuki, M., Narita, H., and Sakamoto, T.: Reconstruction of paleoproductivity in the Sea of Okhotsk over the last $30 \mathrm{kyr}$, Paleoceanography, 19, PA1016, https://doi.org/10.1029/2002PA000808, 2004.

Serreze, M. C., Walsh, J. E., Chapin III, F. S., Osterkamp, T., Dyurgerov, M., Romanovsky, V., Oechel, W. C., Morison, J., Zhang, T., and Barry, R. G.: Observational evidence of recent change in the northern high-latitude environment, Climatic Change, 46, 159207, https://doi.org/10.1023/A:1005504031923, 2000.

Shcherbina, A. Y., Talley, L. D., and Rudnick, D. L.: Direct observations of North Pacific ventilation: Brine rejection in the Okhotsk Sea, Science, 302, 1952-1955, https://doi.org/10.1126/science.1088692, 2003.

Shemesh, A., Burckle, L. H., and Froelich, P. N.: Dissolution and preservation of Antarctic datoms and the effect on sediment thanatocoenoses, Quaternary Res., 31, 288-308, https://doi.org/10.1016/0033-5894(89)90010-0, 1989.

Shiga, K. and Koizumi, I.: Latest Quaternary oceanographic changes in the Okhotsk Sea based on diatom records, Mar Micropaleontol., 38, 91-117, https://doi.org/10.1016/S03778398(99)00041-9, 2000

Shimada, C., Hasegawa, S., Tanimura, Y., and Burckle, L. H.: A new index to quantify diatom dissolution levels based on a ratio of Neodenticula seminae frustule components, Micropaleontology, 49, 267-276, https://doi.org/10.2113/49.3.267, 2003.

Shimada, C., Ikehara, K., Tanimura, Y., and Hasegawa, S.: Millennial-scale variability of Holocene hydrography in the southwestern Okhotsk Sea: diatom evidence, Holocene, 14, 641650, https://doi.org/10.1191/0959683604hl743rp, 2004.

Shimada, C., Tanaka, Y., and Tanimura, Y.: Seasonal variation in skeletal silicification of Neodenticula seminae, a marine planktonic diatom: sediment trap experiments in the NW Pa- 
cific Ocean (1997-2001), Mar. Micropaleontol., 60, 130-144, https://doi.org/10.1016/j.marmicro.2006.04.006, 2006.

Shiono, M.: Two new species of the Thalassiosira trifulta group in late Pliocene sediments of the northwest Pacific ocean, Diatom Res., 16, 83-92, https://doi.org/10.1080/0269249X.2001.9705510, 2001.

Sommer, U. and Lewandowska, A.: Climate change and the phytoplankton spring bloom: warming and overwintering zooplankton have similar effects on phytoplankton, Glob. Change Biol., 17, 154-162, https://doi.org/10.1111/j.1365-2486.2010.02182.x, 2011.

Sorokin, Y. I. and Sorokin, P. Y.: Production in the Sea of Okhotsk, J. Plankton Res., 21, 201-230, https://doi.org/10.1093/plankt/21.2.201, 1999.

Sorokin, Y. I. and Sorokin, P. Y.: Microplankton and primary production in the Sea of Okhotsk in summer 1994, J. Plankton Res., 24, 453-470, https://doi.org/10.1093/plankt/24.5.453, 2002.

Stroeve, J., Holland, M. M., Meier, W., Scambos, T., and Serreze, M.: Arctic sea ice decline: faster than forecast, Geophys. Res. Lett., 34, L09501, https://doi.org/10.1029/2007GL029703, 2007.

Stroeve, J., Serreze, M., Holland, M. M., Kay, J. E., Malanik, J., and Barrett, A. P.: The Arctic's rapidly shrinking sea ice cover: a research synthesis, Climatic Change, 110, 1005-1027, https://doi.org/10.1007/s10584-011-0101-1, 2012.

Sukhanova, I. N., Flint, M. V., Pautova, L. A., Stockwell, D. A., Grebmeier, J. M., and Sergeeva, V. M.: Phytoplankton of the western Arctic in the spring and summer of 2002: Structure and seasonal changes, Deep-Sea Res. Pt. II, 56, 1223-1236, https://doi.org/10.1016/j.dsr2.2008.12.030, 2009.

Syvertsen, E. E.: Ice algae in the Barents Sea: types of assemblages, origin, fate and role in the ice-edge phytoplankton bloom, Polar Res., 10, 277-288, https://doi.org/10.1111/j.17518369.1991.tb00653.x, 1991.

Syvertsen, E. E. and Hasle, G. R.: Thalassiosira bulbosa Syvertsen, sp. nov., an Arctic marine diatom, Polar Biol., 3, 167-172, https://doi.org/10.1007/BF00442648, 1984.

Takahashi, K.: Seasonal fluxes of pelagic diatoms in the subarctic Pacific, 1982-1983, 1986, Deep-Sea Res. Pt. A, 33, 1225-1251, https://doi.org/10.1016/0198-0149(86)90022-1, 1986.

Talley, L. D.: An Okhotsk Sea water anomaly: implications for ventilation in the North Pacific, Deep-Sea Res., 38, S171-S190, https://doi.org/10.1016/S0198-0149(12)80009-4, 1991.

Tuschling, K., Juterzenka, K., Okolodkov, Y. B., and Anoshkin, A.: Composition and distribution of the pelagic and sympagic algal assemblages in the Laptev Sea during autumnal freeze-up, J. Plankton Res., 22, 843-864, https://doi.org/10.1093/plankt/22.5.843, 2000.
Vasilenko, Y. P., Gorbarenko, S. A., Bosin, A. A., Shi, X., Chen, M.-T., Zou, J., Liu, Y., Artemova, A. V., Yanchenko, E. A., and Savenko, M. P.: Millennial mode of variability of sea ice conditions in the Okhotsk Sea during the last glaciation (MIS 4-MIS 2), Quaternary Int., 459, 187-200, https://doi.org/10.1016/j.quaint.2017.09.039, 2017.

Villareal, T. A. and Fryxell, G. A.: Temperature effects on the valve structure of the bipolar diatoms Thalassiosira antarctica and Porosira glacialis, Polar Biol., 2, 163-169, https://doi.org/10.1007/BF00448966, 1983.

Vinnikov, K. Y., Robock, A., Stouffer, R. J., Walsh, J. E., Parkinson, C. L., Cavalieri, D. J., Mitchell, J. F. B., Garrett, D., and Zakharov, V. F.: Global warming and Northern Hemisphere sea ice extent, Science, 286, 1934-1937, https://doi.org/10.1126/science.286.5446.1934, 1999.

von Quillfeldt, C. H.: The diatom Fragilariopsis cylindrus and its potential as an indicator species for cold water rather than for sea ice, Vie Milieu, 54, 137-143, 2004.

von Quillfeldt, C. H., Ambrose Jr., W. G., and Clough, L. M.: High number of diatom species in first-year ice from the Chukchi Sea, Polar Biol., 26, 806-818, https://doi.org/10.1007/s00300003-0549-1, 2003.

Wang, K.-S., Shi, X.-F., Zou, J.-J., Kandasamy, S., Gong, X., $\mathrm{Wu}, \mathrm{Y} .-\mathrm{H}$. , and Yan, Q.-S.: Sediment provenance variations in the southern Okhotsk Sea over the last $180 \mathrm{ka}$ : Evidence from light and heavy minerals, Palaeogeogr. Palaeocl., 479, 61-70, https://doi.org/10.1016/j.palaeo.2017.04.017, 2017.

Wang, W.-L. and Wang, L.-C.: Reconstruction of oceanographic changes based on the diatom records of the central Okhotsk Sea over the last 500000 years, Terr. Atmos. Ocean. Sci., 19, 403411, https://doi.org/10.3319/TAO.2008.19.4.403(IMAGES), 2008.

Yamazaki, T., Inoue, S., Shimono, T., Sakamoto, T., and Sakai, S.: Sea-ice conditions in the Okhotsk Sea during the last $550 \mathrm{kyr}$ deduced from environmental magnetism, Geochem. Geophy. Geosy., 14, 5026-5040, https://doi.org/10.1002/2013GC004959, 2013.

Yasuda, I.: The origin of the North Pacific Intermediate Water, J. Geophys. Res., 102, 893-909, https://doi.org/10.1029/96JC02938, 1997. 